\title{
Biogenic porous silica and silicon sourced from Mexican Giant Horsetail (Equisetum myriochaetum) and their application as supports for enzyme immobilization
}

Anna Sola-Rabada, ${ }^{1 \Psi}$ Padma Sahare,${ }^{2 \psi}$ Graham J. Hickman, ${ }^{1}$ Marco Vasquez, ${ }^{2}$ Leigh T. Canham ${ }^{3}$, Carole C. Perry $^{1 *}$ and Vivechana Agarwal ${ }^{2 *}$

${ }^{1}$ Biomolecular and Materials Interface Research Group, Interdisciplinary Biomedical Research Centre, School of Science and Technology, Nottingham Trent University, Clifton Lane, Nottingham, NG11 8NS, United Kingdom.

${ }^{2}$ Centro de Investigación en Ingeniería y Ciencias Aplicadas, Universidad Autónoma del Estado de Morelos, Av. Universidad 1001, Col. Chamilpa, Cuernavaca, Morelos, 62209, México.

${ }^{3}$ Nanoscale Physics Research Laboratories, University of Birmingham, Edgbaston, Birmingham B15 2TT, United Kingdom.

${ }^{\Psi}$ Authors contributed equally to work

${ }^{*}$ Corresponding authors:

- carole.perry@ntu.ac.uk, +44 11584 86695, Biomolecular and Materials Interface Research Group, Interdisciplinary Biomedical Research Centre, School of Science and Technology, Nottingham Trent University, Clifton Lane, Nottingham, NG11 8NS, United Kingdom

- vagarwal@uaem.mx, +52 777 3297084, Centro de Investigación en Ingeniería y Ciencias Aplicadas, Universidad Autónoma del Estado de Morelos, Av. Universidad 1001, Col. Chamilpa, Cuernavaca, Morelos, 62209, México.

\begin{abstract}
Porous silica-based materials are attractive for biomedical applications due to their biocompatibility and biodegradable character. In addition, inorganic supports such as porous silicon are being developed due to integrated circuit chip compatibility and tunable properties leading to a wide range of multidisciplinary applications. In this contribution, biosilica extracted from a rarely studied plant material (Equisetum Myriochaetum), its conversion to silicon and the potential for both materials to be used as supports for enzyme immobilization are investigated. E. myriochaetum was subject to conventional acid digestion to extract biogenic silica with a \% yield remarkably higher (up to 3 times) than for other Equisetum sp. (i.e. E. Arvense). The surface area of the isolated silica was $\sim 400 \mathrm{~m}^{2} / \mathrm{g}$, suitable for biotechnological applications. Biogenic silicon was obtained by magnesiothermic reduction. The materials were characterized by SEM-EDX, XRD, FT-IR, ICP-OES, TGA and BET analysis and did not contain significant levels of class 1 heavy elements (such as $\mathrm{Pb}, \mathrm{Cd}, \mathrm{Hg}$ and $\mathrm{As}$ ). Two commercial peroxidases, horseradish peroxidase (HRP) and Coprinus cinereus peroxidase (CiP) were immobilized onto the biogenic materials using three different functionalization routes: (A) carbodiimide, (B) amine + glutaraldehyde and $(\mathrm{C})$ amine + carbodiimide. Although both biogenic silica and porous silicon could be used as supports differences in behaviour were observed for the two enzymes. For HRP, loading onto biogenic silica via the glutaraldehyde immobilization technique (route B) was most effective. The loading of CiP showed a much higher peroxidase activity onto porous silicon than silica functionalized by the carbodiimide method (route A). From the properties of the extracted materials obtained from Equisetum Myriochaetum and the immobilization results observed, these materials appear to be promising for industrial and biomedical applications.
\end{abstract}

Keywords Equisetum spp., porous silica, magnesiothermic reduction, enzyme immobilization, enzyme activity 


\section{Introduction}

Equisetum spp. (also known as horsetail) are classified as one of the most ancient species of living vascular plants [1]. A remarkable characteristic of Equisetum spp. is their ability to take up monosilicic acid from the soil and accumulate silica in their tissues [2-4] providing mechanical strength and rigidity to the plant [2-4]. This natural silica, often referred to as biogenic silica or biosilica, is present in the form of amorphous silica [5-8]. The ability of plants to produce biogenic silica with a wide range of morphologies under mild physiological conditions is of great interest to scientists (and industry) as it gives the material exceptional properties, such as ordered hierarchical porous structures applicable for catalysis [9], biosensing [10] and biomedical applications [10]. Further, plants and other biological organisms (i.e. sponges and diatoms) produce silica in amounts corresponding to gigatons per annum, whereas industrial processes merely produce megatons of material [11]. Biogenic silica in plants is present together with a cell wall matrix, including polymers (i.e. cellulose), proteins, other carbohydrates, lipids, metal ions (such as $\mathrm{Ca}, \mathrm{K}, \mathrm{S}, \mathrm{Cl}, \mathrm{Na}, \mathrm{Al}$ and $\mathrm{P}$ ), and phenolic compounds, which also play an important role in the hierarchical structures of biosilica [12-14]. The distribution and amount of silicon and other metal ions vary between individual plant families [7,15] and, within the plant, depending on the anatomical region studied $[2,16,17]$. Horsetail species can be classified into two distinct subgenera based on the stomatal position [18]: Equisetum (i.e. E. arvense) and Hippochaete (i.e. E. hyemale). In these two subgenera (Equisetum and Hippochaete) can be found the giant horsetails E. telmateia and E. myriochaetum, respectively. $E$. myriochaetum is the largest giant horsetail recorded to date, reaching $24 \mathrm{ft}$. in height [19], which is up to 5 times taller than the common horsetail E. arvense ( $\sim \mathrm{ft}$.). E. myriochaetum is native to Mexico (North America), and is known as the Mexican giant horsetail; however, it can be found in other countries of the Americas such as Ecuador, Venezuela, Colombia, Peru, Costa Rica, etc. Studies done with this plant have been mainly based on its potential use as a medicinal plant (herbal extracts) to treat diabetes or kidney diseases [20-22]. However, a few studies have been made on its structural composition and morphology [23,24]. Hence, interest in this plant emerges from examining if the enormous difference in size compared with other Equisetum spp. also affect the properties of the biosilica present (i.e. structures and porosity) and; therefore, its potential applications. For example, porous silica-based materials have attracted great attention in hosting biological catalysts due to their biocompatibility and biodegradable character [25]. Great advancements have been made in the use of porous silica materials for enzyme immobilization [26], however, an appropriate immobilization strategy is required depending on the biomolecule, the silica source and the targeted application [26,27]. Alternative inorganic supports like porous silicon (PSi) have also been widely employed in this field [28-30]. For example, acetylcholinesterase immobilized on silicon surface showed enhanced storage stability, retention of enzymatic activity, thermal stability and $\mathrm{pH}$ stability [31]. $\beta$-Glucuronidase attached to porous silicon surface through a Si-C bond displayed high activity and photoluminescence $(\mathrm{PL})$ properties of the substrate were retained [28]. Glutathione-S-transferases immobilized onto porous silicon multilayer thin films resulted in enhanced enzyme function in contrast to that observed for the enzyme free in solution [32]. Further interest in PSi materials by the scientific community has been shown due to its compatibility with chip-based technologies, easy fabrication, tunable properties and multidisciplinary applications [33-37]. Due to their high surface area and photoluminescence nature in the visible region they can serve for a vast array of applications including chemical [38-40] and biological sensors [41,42] as well as optoelectronics devices [43]. Similarly to porous silica, PSi is biodegradable [44] and its surface chemistry can be easily modified [45] allowing this material to entrap molecules such as proteins [46], DNA [47], and other biomolecules whose release can be controlled to serve as drug delivery systems [48]. In our previous work, immobilization of an industrially important peroxidase enzyme from Coprinus cinereus onto electrochemically synthesized PSi was investigated for increasing its shelf life against hydrogen peroxide [30]. Further, Cytochrome $C$ was co-immobilized with peroxidase to increase the halflife of the enzyme by acting as a reducing agent for the removal of oxidative equivalents during catalytic reaction [49]. In this current study, the potential of biosilica extracted from a rarely studied plant (E. Myriochaetum), its conversion to silicon and possible applications of both biogenic materials as supports for enzyme immobilization are investigated. 


\section{Materials and methods \\ 2.1. Materials}

Nitric acid $\left(\mathrm{HNO}_{3}, 70 \%\right)$, sulphuric acid $\left(\mathrm{H}_{2} \mathrm{SO}_{4},>95 \%\right)$, acetic acid $\left(\mathrm{CH}_{3} \mathrm{COOH}\right.$, laboratory reagent grade), ethanol ( $\mathrm{EtOH}, 99 \%)$, magnesium powder (99\%) hydrochloric acid $(\mathrm{HCl}, 36 \%)$ and sodium hydroxide pellets $(\mathrm{NaOH}, \geq 97.0 \%)$ were obtained from Fisher Scientific. 10-Undecenoic acid 98\%, 2, 2'- Azino-bis(3-

ethylbenzothiazoline-6- sulphonic acid) diammonium salt (ABTS), 3-aminopropyltriethoxysilane (APTES), NHydroxysuccinimide (NHS), N-(3-dimethylamonopropyl)-N' ethylcarbodimiide hydrochloride (EDC), glutaradehyde (GDA, 50\%) and peroxidase from horseradish (Type VI- A, salt free, lyophilized powder 950-2000 U/mg) were obtained from Sigma Aldrich. A commercial peroxidase, Baylase ${ }^{\circledR}$ RP; hereafter named Coprinus cinereus peroxidase (CiP), was kindly donated by Bayer Mexico (Puebla, Mexico). Phosphate buffer was prepared by using monobasic potassium phosphate also from Sigma Aldrich. Succinic anhydride was obtained from Fluka. Standard solutions for each element were prepared from 1000 ppm stock solutions purchased from BDH Laboratory Supplies. Distilled-deionized water $\left(\mathrm{ddH}_{2} \mathrm{O}\right)$ with conductivity less than $1 \mu \mathrm{S} \mathrm{cm}^{-1}\left(25^{\circ} \mathrm{C}\right)$ was used for all experiments.

\subsection{Silica extraction}

Equisetum myriochaetum was collected from Xochicalco (Mexico) in July-October 2015. The height of the plant was 6-7 feet. Fresh samples were stored in dry, dark conditions at room temperature. Plant material was separated into stems and branches and dried in an oven at $50^{\circ} \mathrm{C}$ prior to acid digestion in concentrated $\mathrm{HNO}_{3} / \mathrm{H}_{2} \mathrm{SO}_{4}(4: 1), 25 \mathrm{~g}$ of dry starting material was processed with $1 \mathrm{~L}$ of acid. To avoid acid burning, plant material was first covered with nitric acid and the sulphuric acid was then added carefully into the system. The mixture was stirred and left in a fume hood until a fine white precipitate was obtained and the release of oxides of nitrogen had stopped, usually around $48 \mathrm{~h}$. Precipitates were isolated and washed with copious amounts of deionized water until the $\mathrm{pH}$ value of the water was around 5 . The samples were then lyophilised before being heat-treated under air at $650^{\circ} \mathrm{C}$ for $5 \mathrm{~h}$ with a heating rate of $10^{\circ} \mathrm{C} / \mathrm{min}$. Simultaneously, a non-giant Equisetum spp., arvense, was also treated similarly in order to compare properties of the silica extracted.

\subsection{Magnesiothermic reduction of silica}

Magnesium and biogenic silica were mixed at a molar ratio 1.5:1. The mixture was then heated in a ceramic tube furnace at $650^{\circ} \mathrm{C}$ for $2 \mathrm{~h}$ in an Argon (Ar) atmosphere. Leaching of side products (i.e. $\mathrm{MgO} \mathrm{Mg}_{2} \mathrm{Si}, \mathrm{Mg}_{2} \mathrm{SiO}_{4}$, and $\mathrm{SiO}_{2}$ ) was carried out by the addition of a $2 \mathrm{M} \mathrm{HCl}$ solution at $70^{\circ} \mathrm{C}$ for $1 \mathrm{~h}$. The collected product was washed 3 times with $\mathrm{EtOH}$ and the resulting solids treated with a $2 \% \mathrm{HF}$ solution. After 10 seconds, aliquots of water were added. The final product was washed three times with $\mathrm{EtOH}$ and dried at $120^{\circ} \mathrm{C}$ for $4 \mathrm{~h}$ in an $\mathrm{Ar}$ atmosphere. All heat treatments were performed with a heating rate of $10^{\circ} \mathrm{C} / \mathrm{min}$.

\subsection{Silica and silicon functionalization}

Three different functionalization routes (see Fig.1) were compared to determine the highest protein loading on biogenic silica; for silicon the established route A and B were applied exclusively. In the first route (A), silicon and biogenic silica substrates were functionalised using 10-undecenoic acid in the manner previously described [49]. For the second route (B) the biogenic silica was first modified through the addition of $100 \mathrm{mM} 3$-aminopropyl groups (i.e. APTES or APDEMS) in $0.5 \mathrm{M}$ acetic acid for $30 \mathrm{~min}$. The substrate was washed 3 times with EtOH and treated with glutaric dialdehyde $\left(2 \%\right.$ incubated for $2 \mathrm{~h}$ at $\left.57^{\circ} \mathrm{C}\right)$. In this case, protein loading $(1 \mathrm{mg} / \mathrm{mL})$ was for $2 \mathrm{~h}$ at $4{ }^{\circ} \mathrm{C}$ in $1 \mathrm{M}$ phosphate buffer ( $\mathrm{pH}$ 6). The final route (C) used $100 \mathrm{mM}$ succinic anhydride in $0.2 \mathrm{M}$ phosphate buffer $(\mathrm{pH} 7.5)$ for $4 \mathrm{~h}$ as an alternative linker for amine functionalised silica substrates. The substrate was washed 3 times with $\mathrm{EtOH}$ prior to protein loading in the manner of route $(\mathrm{A})$. 


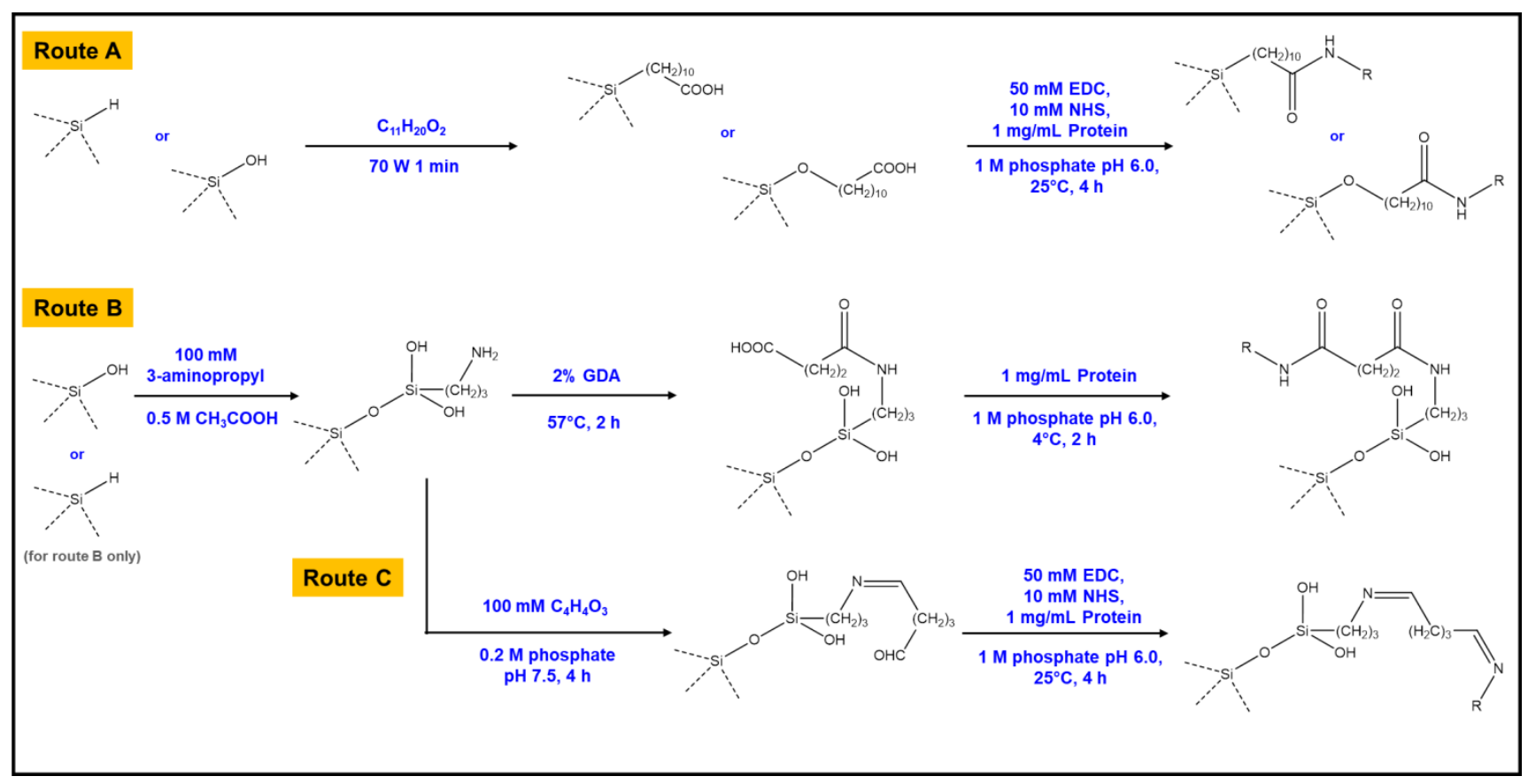

Fig. 1. Functionalization routes used for protein loading to biogenic material/s.

\subsection{Enzyme kinetic assays}

The oxidation of $10 \mu \mathrm{M}$ of 2,2'-azino-bis(3-ethylbenzothiazoline-6-sulphonic acid) (ABTS) was monitored by measuring absorbance over time at $405 \mathrm{~nm}$ using a Cary50 or a Perkin Elmer 950 UV-Vis spectrophotometer. The reaction was catalyzed with $10 \mathrm{mM} \mathrm{H}_{2} \mathrm{O}_{2}$ and conducted in $60 \mathrm{mM}$ phosphate buffer (pH 6.0). Activity of the enzyme loaded particles, washes, unloaded particles and crude enzyme was measured and used to calculate enzyme loading based on $\mathrm{U} / \mathrm{m}^{2}$.

\subsection{Statistical testing}

Significance between means was tested in Microsoft excel using the students t-test function $(n=4)$, a $P$ value $\leq 0.05$ was accepted as signifying a significant difference. The tests were two-tailed and the variance between the samples was not assumed to be equal.

\subsection{Characterization}

The morphology of the samples was determined by SEM (JEOL JSM-840A operating in secondary electron mode, $20 \mathrm{kV}$ accelerating voltage). Samples were attached to aluminum stubs using double-sided carbon adhesive tape and carbon coated (Edwards, sputter coater S150B). The crystallinity of the precipitates obtained was characterized using XRD (PANalytical X'Pert PRO, Cu Ka radiation with a wavelength of $1.54056 \AA$ ). Ground samples were packed into an aluminum sample holder and scanned from $5^{\circ}$ to $80^{\circ}$ of $2 \theta$ at an accelerating voltage of $45 \mathrm{kV}, 40 \mathrm{~mA}$ filament current, using a scan speed of $0.02^{\circ} \mathrm{s}^{-1}$ at room temperature. Diffraction patterns were analyzed using the X'Pert-HighScore Plus (Version 2.0a) program for diffractogram manipulation, background determination and peak identification. FTIR spectrometer (Agilent Technologies Cary 640/660 attached with ZnSe crystal) or ATR (Perkin Elmer Spectrum 100 FTIR Spectrometer with Diamond/KRS-5 crystal) was used to detect the functional groups present in the samples. Spectra were averaged from 32 scans at $4 \mathrm{~cm}^{-1}$ resolution with air as a background. Diffuse reflectance infrared Fourier transform spectroscopy (DRIFTS) was used to identify changes in surface chemistry using a Thermo Scientific Nicolet 6700 FT-IR fitted with a Spectra Tech Inc. DRIFTS accessory purged using a Balston FT-IR purge gas generator and blank spectra taken using milled KBr. DRIFT spectra comprising 512 scans between $4000-400 \mathrm{~cm}^{-1}$ were collected with a resolution of 2 $\mathrm{cm}^{-1}$. The organic content was determined by TGA (Mettler Toledo TGA/SDTA 851 ${ }^{\mathrm{e}}$ ). Samples were heated at 10 
${ }^{\circ} \mathrm{C} \cdot \mathrm{min}^{-1}$ from $30{ }^{\circ} \mathrm{C}$ to $900{ }^{\circ} \mathrm{C}$ in air to ensure complete combustion of all organic material. The sample surface area and the $\mathrm{N}_{2}$ adsorption-desorption isotherms were obtained on approximately $100 \mathrm{mg}$ of sample powder by Gas adsorption analysis (Quantochrome Nova 3200e). Samples were degassed at $100^{\circ} \mathrm{C}$ overnight prior to each analysis. The surface area was determined by the Brunauer-Emmett-Teller (BET) method [50] using a five-point adsorption isotherm in the relative pressure range of $P / P_{0}=0.05 / 0.3$ at $77.35 \mathrm{~K}$. Sample porosity (pore size distribution) was obtained by the Barrett-Joyner-Halenda (BJH) method [51] from the desorption branch of the isotherm. The concentration of silicon ( $\mathrm{Si})$, calcium $(\mathrm{Ca})$, potassium $(\mathrm{K})$, phosphorus $(\mathrm{P})$, magnesium $(\mathrm{Mg})$, aluminium (Al) and strontium (Sr) in the samples was determined by using ICP-OES (Optima 2100DV). A full spectrum qualitative analysis was also carried out in order to discard the presence of heavy metals such as lead $(\mathrm{Pb})$. For native material, $50 \mathrm{mg}$ were fused into a Ni crucible with solid ground $\mathrm{NaOH}(5 \mathrm{~g})$ at $400{ }^{\circ} \mathrm{C}$ during 15 min using a temperature ramp of $10^{\circ} \mathrm{C} \cdot \mathrm{min}^{-1}$. Collected samples were dissolved in distilled water and after $1 \mathrm{~h}$ acidified with concentrated nitric acid $\left(\mathrm{HNO}_{3}\right)$. Final samples (1000 ppm in $10 \% \mathrm{HNO}_{3}$ ) were filtered through a $0.45 \mu \mathrm{m}$ disc filter prior to analysis. For acid digested plant material, $50 \mathrm{mg}$ of sample was added to a $4 \mathrm{M} \mathrm{NaOH}$ solution and sonicated until complete dissolution. Standard solutions for each element (detected in the qualitative analysis) were prepared from $1000 \mathrm{ppm}$ stock solutions purchased from BDH Laboratory Supplies. The amount of each element was determined by comparison with standards of known concentrations (0-100 ppm, correlation coefficient of 0.999$)$ using a wavelength $(\mathrm{nm})$ of 251.6 for Si, $317.9(\mathrm{Ca}), 766.5(\mathrm{~K}), 213.6(\mathrm{P}), 285.2(\mathrm{Mg}), 396.1$ (Al) and $407.8(\mathrm{Sr})$.

\section{Results and Discussion}

\subsection{Equisetum myriochaetum: structural characteristics and composition}

Native E. myriochaetum was studied to identify the structural and elemental composition of the samples (branch and stem). SEM analysis (Fig. 2a) showed outer spotted surface along with stomatal openings (left) typically observed for Equisetum spp. and inner multi-laminate structure (right) $[2,16]$. It should be noted that the stomata observed in common horsetail (i.e. Equisetum Arvense) is morphologically different than that observed for giant horsetail (i.e. Equisetum Myriochaetum), presenting in this case radiating ribs around the stomatal pore (Fig. 2a inset). This characteristic ribs are thought to be present in mature stomata, i.e. formed late during the stem development, and are composed of cellulose impregnated with silica [52]. Elemental analysis of Equisetum myriochaetum, cf. EDX spectra of the stem (Fig. 2b), showed the presence of a wide range of elements including the essential elements for the plant growth such as $\mathrm{K}, \mathrm{Ca}, \mathrm{Mg}, \mathrm{S}, \mathrm{Cl}$, and $\mathrm{P}$; and other non-essential elements such as Si was, as expected, detected in the plant material.
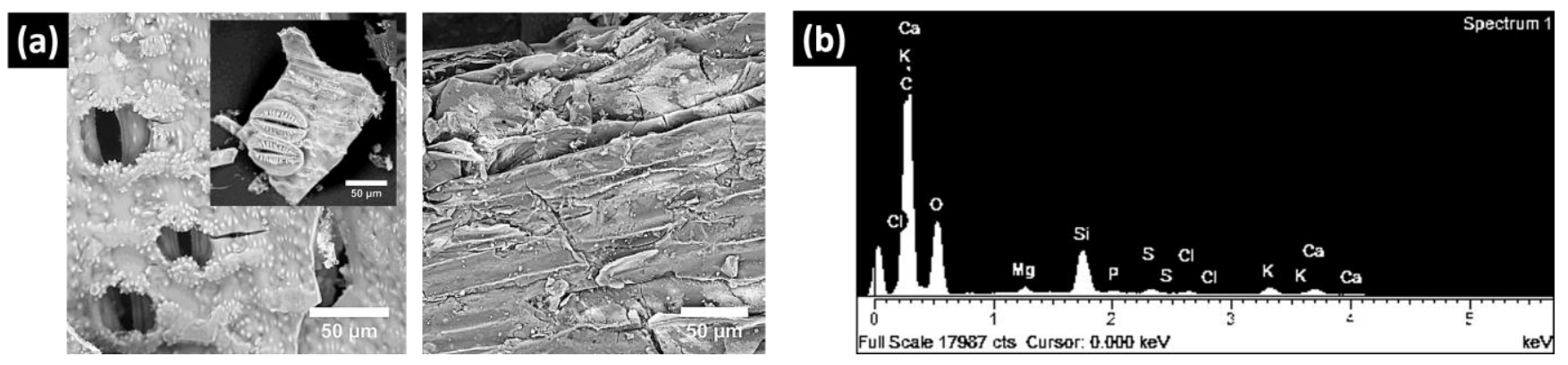

Fig. 2. (a) Electron micrographs of Equisetum Myriochaetum plant showing outer spotted surface (left) with stomata shape (inset) and inner multi-laminate structure (right); and (b) typical EDX spectra of Equisetum myriochaetum. All elements detected in the sample are labelled.

ICP-OES analysis showed that the silica present in the stems and branches was $28 \pm 5 \%$ and $26 \pm 2 \%$, respectively. Other elements, such as $\mathrm{K}, \mathrm{Ca}, \mathrm{P}, \mathrm{Mg}, \mathrm{Al}$ and $\mathrm{Sr}$ were also detected in the samples (listed in order of decreasing \%) (Supplementary material, Table S1). Although, Na could not be quantified due to sample preparation procedure, its presence in the plant material could not be discounted [53]. XRD analysis of the native plant samples revealed the typical diffraction patterns of cellulose (Supplementary material, Fig. S2). Cellulose can exist in many polymorphs (Cellulose I, II, III and IV with additional sub-classifications) due to the hydroxyI 
groups within the structure being involved either in intra- or intermolecular hydrogen bonding, which results in a different arrangement of atoms throughout the structure [54]. However, the predominant naturally occurring structure in nature is Cellulose I [55]. This polymorph can present two different crystalline structures: triclinic (la) and monoclinic $(I \beta)$, with the latter being most frequently found in plants [55]. Both samples contained cellulose I $\beta$ with a primary peak at $2 \Theta \sim 22.5^{\circ}$ corresponding to the (002) plane; and, a secondary broad peak $\left(2 \Theta \sim 16.0^{\circ}\right)$ corresponding to the overlap of the $(101)$ and $(1 \overline{01})$ planes $[54,56]$. The reflection at $2 \Theta \sim 34.7^{\circ}$ was attributed to the (040) plane [54].

Thermal decomposition (TGA analysis) of the plant material showed a slightly larger total \% weight loss (\% wt.) for the stems compared to the branches, being $74 \pm 3 \%$ and $72 \pm 1 \%$, respectively. The organic composition present in this species was found to be $\sim 10 \%$ less than in other horsetail species such as $E$. arvense

(Supplementary material, Table S3). As previously reported for Equisetum ssp. [16], four stages of weight loss were observed (Supplementary material, Table S1). In Stage 1, desorption of water and volatile organic oils occurs at $\mathrm{T}<150^{\circ} \mathrm{C}$. In Stage $2\left(180-380^{\circ} \mathrm{C}\right)$, the degradation of hemicellulose and cellulose by pyrolysis takes place, the maximum rate of weight loss occurring between $286-296{ }^{\circ} \mathrm{C}$ [57]. In Stage 3, degradation of lignin occurs $[58,59]$. The maximum rate of weight loss at this stage however occurs at different temperatures for stems and branches due to the complex structure of lignin thermal stability being known to vary between types and species of plants [60], and within different parts of the same species [16] in this case $\sim 421^{\circ} \mathrm{C}$ and $\sim 450{ }^{\circ} \mathrm{C}$, for stem and branch, respectively. Stage $4\left(800-900^{\circ} \mathrm{C}\right)$ is attributed to the dehydroxylation of silanol groups [61], it was only observed as a loss in weight for the stem, which is in agreement with our previous findings [16]. This data suggested that similarities in composition exist between distinct genera of Equisetum ssp. even if they are grown in different climates, soil composition, etc.

\subsection{Biogenic silica isolated from Equisetum myriochaetum}

After acid digestion and heat treatment of the plant material, the collected samples were mainly composed of silica as seen by XRD and ATR analysis (Supplementary material, Fig. S4). DRIFT technique was also used to characterize the material (Fig. 3). Spectra of the material isolated from E. myriochaetum (Fig. 3) exhibited absorption peaks which would be expected for silica, with the following major assignments; peaks at $\sim 818,1074$ and $1868 \mathrm{~cm}^{-1}$ can be attributed to Si-O-Si [62], $\sim 978 \mathrm{~cm}^{-1}$ to Si-OH [62], $\sim 1631 \mathrm{~cm}^{-1}$ to a polymeric state of $\mathrm{H}_{2} \mathrm{O}$ [63]. Absorbance above $3000 \mathrm{~cm}^{-1}$ is attributed to $\mathrm{O}-\mathrm{H}$ stretching mode either in $\mathrm{H}_{2} \mathrm{O}$ or $\mathrm{Si}-\mathrm{OH}$ groups [62,64], the sharp peak $\sim 3746 \mathrm{~cm}^{-1}$ representing free (no H-bonding) silanol groups [65]. Additional peaks $\sim 2929 \mathrm{~cm}^{-1} \mathrm{can}_{\text {be }}$ attributed to $\mathrm{C}-\mathrm{H}$ [64] and explained as the residual organic component of the material previously detected by TGA (Supplementary material Fig. S2).

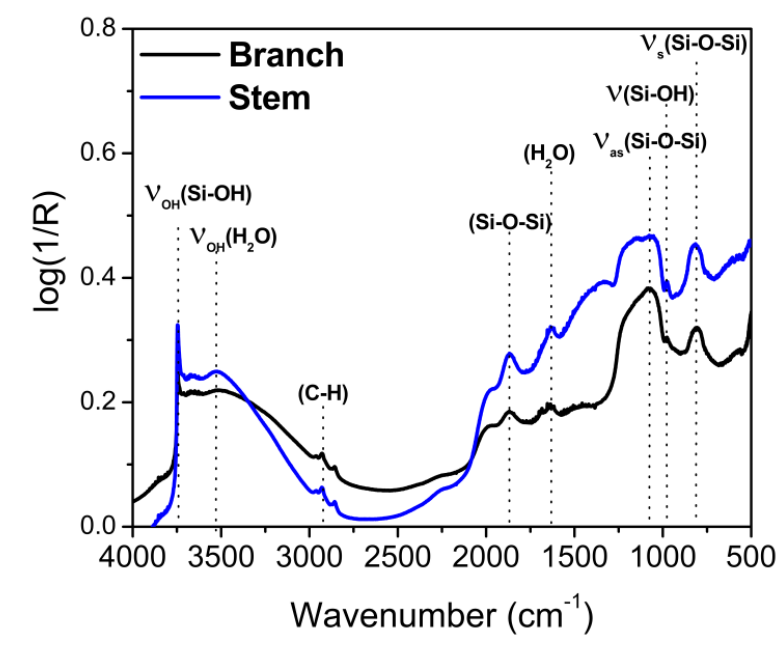

Fig. 3. DRIFTS spectra of acid digested and heat treated E. myriochaetum branches and stems. 
The purity of the biogenic silica was higher than $95 \%$ since the $\%$ weight loss of the samples was less than $5 \%$ (Supplementary material Table S3), this being attributed to traces of other biominerals that can be present in these samples, such as $\mathrm{KCl}$ [16] as evidenced from ICP-OES results (Supplementary material Table S1) by the detection of $\mathrm{K}(\sim 7 \%)$ and traces of other elements such as $\mathrm{P}, \mathrm{Mg}, \mathrm{Al}$ and $\mathrm{Sr}$. Note, Ca was completely removed from the initial sample. Further, the final biogenic silica did not show the presence of heavy metals such as $\mathrm{Pb}$. The \% yield of this process was for the branches remarkably much higher (up to 3 times more) than other Equisetum ssp. (Supplementary material Table S5). Therefore, biogenic material from branches was chosen to be reduced to silicon. The surface area of the isolated material was $\sim 400 \mathrm{~m}^{2} / \mathrm{g}$ (Table 1), this value being slightly higher for stems. Further, the surface area were more than five times higher than that observed for $E$. Arvense and the pore size was seen to be monodisperse (Supplementary material Fig. S6).

Table 1 The surface area, pore size and volume obtained from $\mathrm{N}_{2}$ adsorption measurements.

\begin{tabular}{llll}
\hline Biogenic material & $\mathrm{SSA}\left(\mathrm{m}^{2} \cdot \mathrm{g}^{-1}\right)$ & Pore size $(\mathrm{nm})$ & $\mathrm{V}_{\text {pore }}\left(\mathrm{cc} \cdot \mathrm{g}^{-1}\right)$ \\
\hline Silica (stem) & $412 \pm 17$ & $4.9^{\mathrm{a}}$ & $0.6^{\mathrm{b}}$ \\
Silica (branch) & $384 \pm 13$ & $4.9^{\mathrm{a}}$ & $0.6^{\mathrm{b}}$ \\
Silicon (branch) & 287 & 12.1 & 0.9 \\
\hline
\end{tabular}

a Std. Dev. $<0.02$ and ${ }^{\text {bStd. Dev. }<0.1}$

\subsection{Biogenic silica reduction (Magnesiothermic process)}

Silica was successfully reduced to silicon as shown by XRD and ATR in Fig. 4. The XRD diffraction pattern (Fig. 4a) of biogenic silica (red line) showed a broad peak centered at $\sim 22^{\circ}$ corresponding to amorphous silica; however, for the biogenic silicon, three diffraction peaks were observed at $28.56^{\circ}, 47.44^{\circ}$ and $56.21^{\circ}$ corresponding to the (111), (220) and (311) planes respectively, of crystalline silicon with the reference pattern: 00-027-1402 [66]. FTIR spectra (Fig. 4b), showed typical vibration modes for silicon oxide at $1078 \mathrm{~cm}^{-1}, 960 \mathrm{~cm}^{-}$ ${ }^{1}$ and $800 \mathrm{~cm}^{-1}$, corresponding to the antisymmetric Si-O-Si stretching, Si-OH stretching and symmetric O-Si-O stretching modes, respectively [62]. FTIR spectrum of biogenic silicon showed a peak $\sim 2045 \mathrm{~cm}^{-1} \mathrm{corresponding}^{-}$ to $\mathrm{Si}-\mathrm{H}$ stretching and a peak $\sim 2145 \mathrm{~cm}^{-1}$ associated to stretching mode of $\mathrm{SiH}_{3}$ [67]. The oxide-related peaks were significantly decreased (blue line) after magnesiothermic reduction, confirming the final product was mainly comprised biogenic silicon.
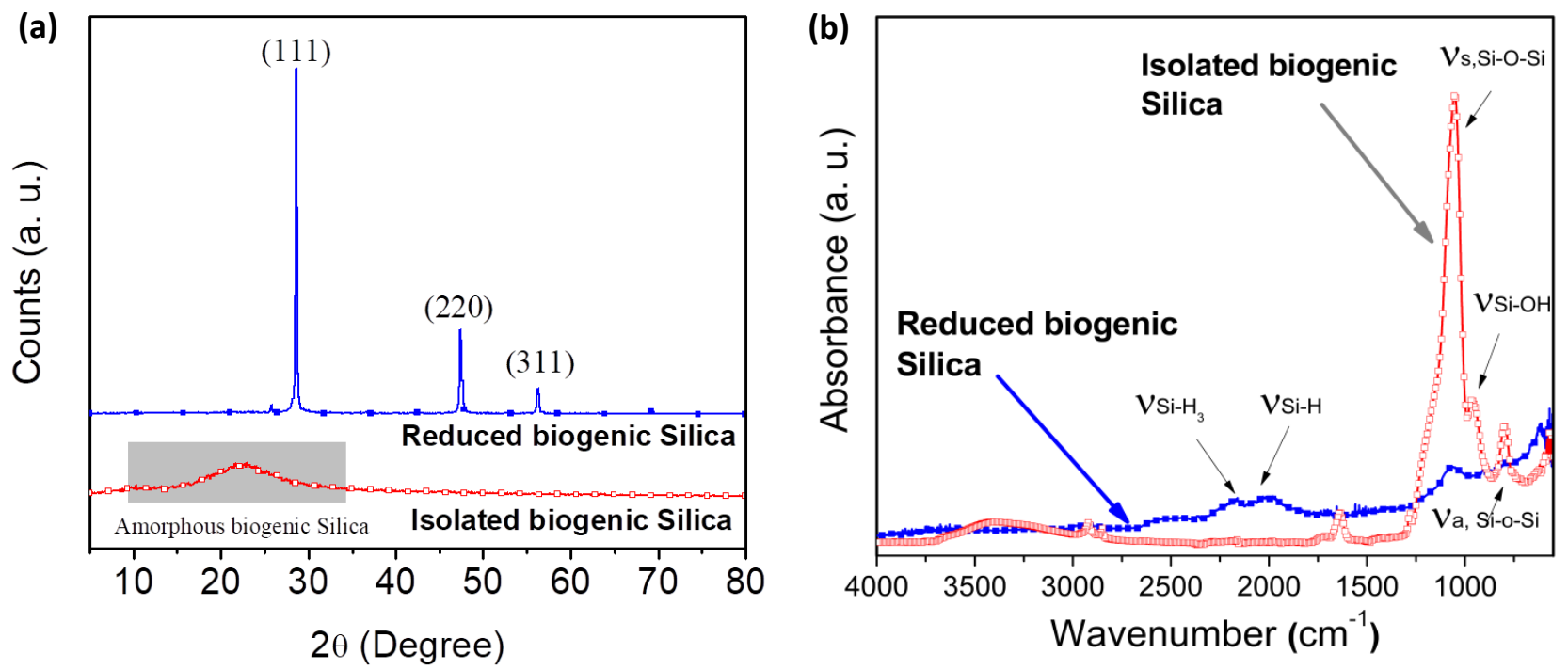
Fig. 4. (a) XRD diffractograms and (b) FTIR spectra of extracted biogenic silica (red line) and reduced biogenic silica (blue line).

The surface morphology of the biogenic silicon as studied by SEM (Fig. 5) showed an homogeneous distribution of pores with average diameter $(n>30)$ of $100 \pm 25 \mathrm{~nm}$. BET analysis showed a reduction of the surface area but an increase of the pore size and pore volume (Table 1). This could be explained as some of the structure was broken after magnesiothermic treatment with larger openings being present on the surfaces of the microparticles.
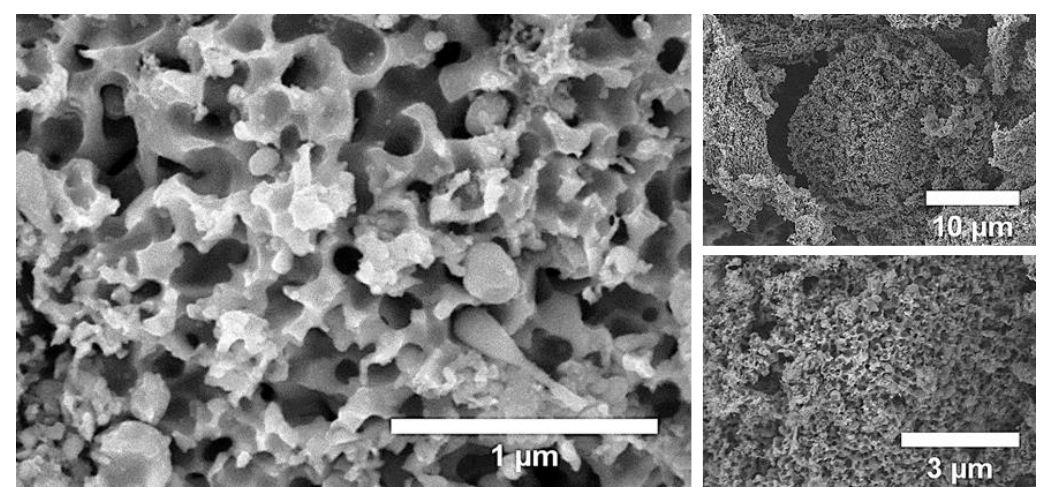

Fig. 5. SEM images of the biogenic silicon after magnesiothermic treatment.

\subsection{Biogenic material functionalization}

After acid digestion and heat treatment of the plant material, the biogenic surface was functionalised to promote enzyme loading. The DRIFT technique was used to characterize the biogenic silica after each stage of functionalization due to its enhanced sensitivity to surface groups (Fig. 6a). In Supplementary material (Fig. S7) are found additional spectra for stems. After treatment with undecylenic acid for route (A) all materials exhibited an increase in the number of peaks attributed to the $\mathrm{C}-\mathrm{H}$ chain. No new peaks were observed above $3000 \mathrm{~cm}^{-1}$ suggesting the presence of new saturated $\mathrm{C}-\mathrm{H}$ bonds, however little evidence of $\mathrm{C}=\mathrm{O}\left(\sim 1700 \mathrm{~cm}^{-1}\right)$ was observed in the spectra. For routes $(B)$ and $(C)$ treatment with 3-aminopropyl groups also resulted in a change in the unsaturated $\mathrm{C}-\mathrm{H}$ region; new peaks were observed $\sim 3300-3380 \mathrm{~cm}^{-1}$ and $1590 \mathrm{~cm}^{-1}$ representing $\mathrm{N}-\mathrm{H}$ and C-N respectively [68] On treatment with GDA (route B) the appearance of a peak at $\sim 1700 \mathrm{~cm}^{-1}$ suggested the introduction of $\mathrm{C}=\mathrm{O}$ groups from the aldehyde $[69,70]$. On treatment with succinic anhydride (route $\mathrm{C}$ ), several new peaks appeared at $\sim 1720,1460$ and $1380 \mathrm{~cm}^{-1}$ which are interpreted as the introduction of $-\mathrm{COOH}$ groups to the surface.
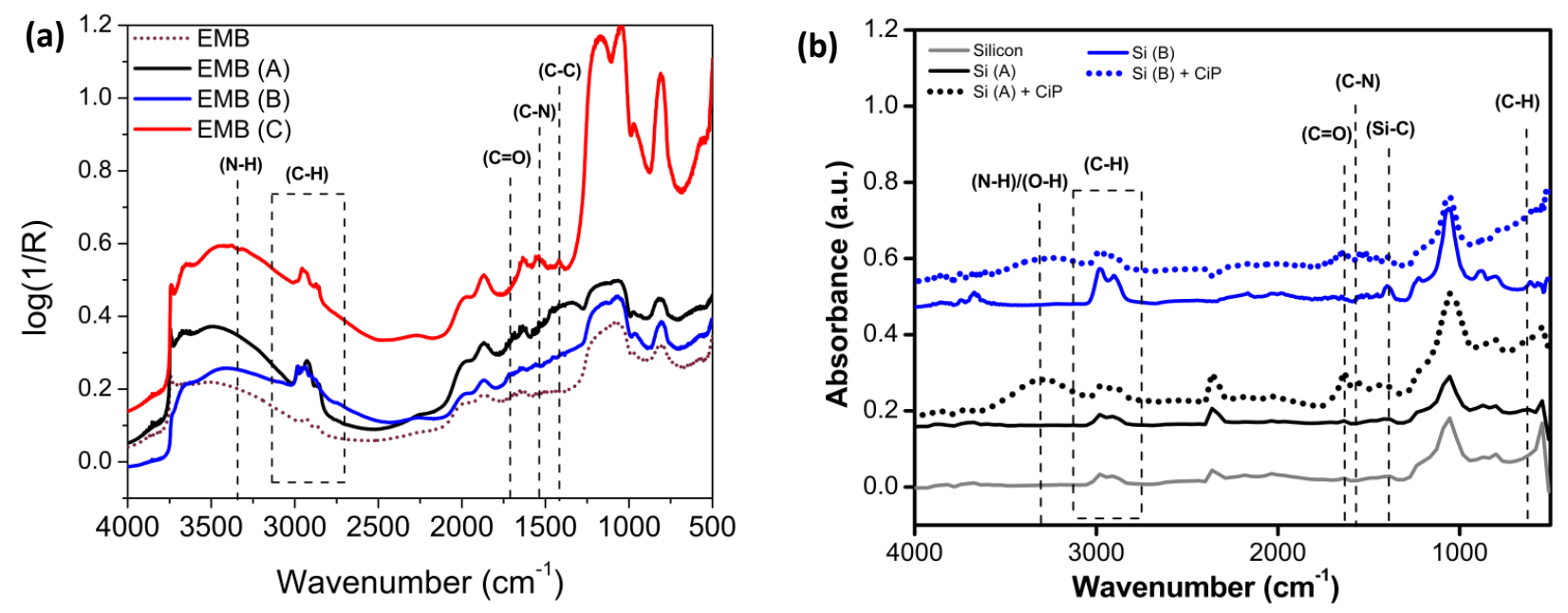

Fig. 6. (a) DRIFTS spectra of E. myriochaetum branches (EMB) after functionalization by route A, B and C; and, (b) FTIR spectra of each step of immobilization of Silicon + CiP by routes A and B. 
Note that, silicon surfaces are typically functionalized following route $A$, however, as anticipated, the biogenic silica functionalized using route $B$ (treatment with GDA) showed the highest enzyme loading. Therefore, this functionalization method (route B) was also applied for biogenic silicon for a comparison study. Further FTIR spectra for each step of immobilization onto functionalized microparticles (by route A and B) for CiP (Coprinus cinereus peroxidase) was studied for biogenic materials, cf. FTIR spectra of immobilized peroxidase onto functionalized silicon (Fig. 6b). In Supplementary material (Fig. S8) are found spectra of immobilized peroxidase onto functionalized silica. It should be noted that characteristic silica peaks are still observed in the silicon spectrum, suggesting not all silica has been converted to silicon. After immobilization of the CiP, there was an intense peak $\sim 1650 \mathrm{~cm}^{-1}$ corresponding to the amide I bond specific for enzymes arising from stretching vibrations of the $\mathrm{C}=\mathrm{O}$ (70 to $85 \%$ ) and $\mathrm{C}-\mathrm{N}$ groups (10 to 20\%) [71]. The intensity increase of the broad peak around $3000-3400 \mathrm{~cm}^{-1}$ would indicate the presence of peroxidase due to intermolecular hydrogen bond arising from $-\mathrm{NH}_{2}$ and $-\mathrm{OH}$ groups in the peroxidase [72-74]. For route $\mathrm{B}$, the peaks at $1410 \mathrm{~cm}^{-1}$ from deformation modes of the Si- $\mathrm{CH}_{2}$ from the ethoxy moieties [75] and at $1625 \mathrm{~cm}^{-1}$ from $\mathrm{NH}_{2}$ bend [76] indicated the presence of 3-aminopropyl on the microparticles. Characteristic IR peaks from functionalization (previously described in Fig.6a) were also observed for silicon microparticles.

\subsection{Activity of immobilized enzymes}

After functionalization of biogenic silica by the 3 routes, peroxidase from horseradish (HRP) was loaded onto the different substrates over a $4 \mathrm{~h}$ period and washed three times with $60 \mathrm{mM}$ phosphate buffer $(\mathrm{pH} 5)$ to remove unbound enzyme. The enzyme activity of the loaded substrates was then determined (Fig. 7). An unfunctionalized commercial Silicon sample from pSiMedica (SSA $=400 \mathrm{~m}^{2} \cdot \mathrm{g}^{-1}$, pore size $=10 \mathrm{~nm}$ ) was employed to compare enzyme loading effectiveness with functionalization. Measured enzyme activity revealed significant differences in HRP loading between the substrates. In the case of both E. myriochaetum branch (EMB) and stem (EMS) derived substrates, loading without functionalization achieved a comparable result. In the case of functionalization using undecylenic acid $(\mathrm{A})$ both substrates showed the lowest activity and performed significantly worse for EMB than loading without functionalization. Since this method was designed for silicon substrates (refer to $\mathrm{Si}$ and $\mathrm{Si}(\mathrm{A})$ ) it was understandable that the route performed poorly with silica which lacks the desired $\mathrm{Si}-\mathrm{H}$ groups necessary for interaction. Additionally, previous immobilization studies have suggested that HRP enzyme is absorbed into the pore spaces of silica particles [77]. For the biogenic silica, with average $5 \mathrm{~nm}$ pore size (Table 1), this adsorption could be limited due to the enzyme dimensions (elongated shape of $6.4 \times 3.7$ $\mathrm{nm})$. For the 3-aminopropyl functionalized substrates made with the aldehyde linker (B), for EMB at least, significantly greater loading was achieved compared to $A$ and $C$ for EMB. However, for the 3-aminopropyl functionalized substrates with EDC/NHS linker $(\mathrm{C})$ the resulting loading was not significantly different to the nonfunctionalized control and showed greater variability between replicates. What was apparent from the functionalization, loading and HRP activity studies was that the functionalization of biosilica is not a prerequisite for loading enzyme onto the biogenic substrate. Biogenic silica with readily available surface hydroxyls (Fig. 7) can intrinsically bind protein through mechanisms such as hydrogen bonding and electrostatic forces [78]. Under

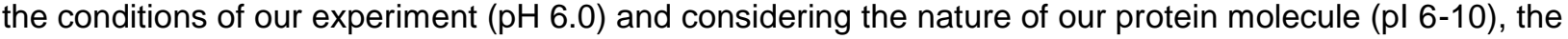
potential for electrostatic interactions exist. Covalent tethering of the protein to the substrate is however desirable in many applications (i.e. if conditions will not permit/sustain electrostatic interactions). For this functionalization of the biogenic silica is required but the choice of the linker can obviously greatly influence the efficiency of the loading. That the use of 10-undecenoic acid had a negative impact on loading was interesting and suggests that the presence of the undecylenic acid blocked the inherent binding mechanism of the non-functionalized material. The protein loading reaction for routes $A$ and $C$ were the same, functionalization with 3-aminopropyl groups did not significantly influence binding compared to the non-functionalized material. Although route $B$ provided some evidence of higher loading than other routes it is difficult to suggest on the basis of this work a definitive route for the loading of HRP to biogenic silica, this suggests that further optimization in the loading strategy is possible. 


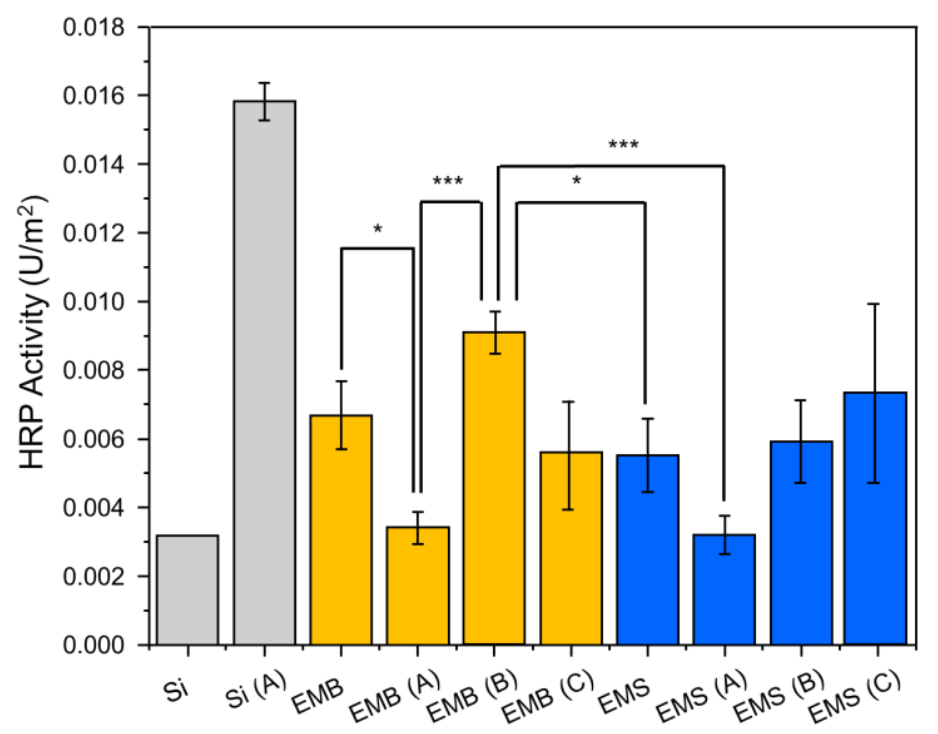

Fig. 7 HRP activity of differently functionalized substrates in Units $\left(\mathrm{U} / \mathrm{m}^{2}\right)$. EMB and EMS represent acid digested and heat treated $E$. myriochaetum (branches and stems respectively), Si represents a commercial porous silicon $(n=2)$. A, B and $C$ represent the different functionalization pathways. Significance was tested between EMB and EMS substrates and represented as follows * $(P<0.05),{ }^{* * *}(P<0.001), n=4$.

As protein loading on biosilica was best achieved by following route $B(G D A)$, a comparison study with the biogenic silicon (from branches) was performed by using CiP peroxidase. With the two well-known functionalization techniques (A and B) for enzyme immobilization, CiP peroxidase showed much higher activity. Both routes found the accessibility to the immobilized enzymes into the microparticles to be key to their activities. Using route $A$, which is considered specific for silicon, $28-31 \%$ of the expected peroxidase activity was found; however, this value was reduced to $21-23 \%$ when biogenic silica was used. In contrast, using the GDA method (route B, specific for silica) a much lower activity was found for silicon compared to silica, being $14-16 \%$ of the expected activity for silicon and $20-22 \%$ for silica microparticles. From these results it was concluded that enzyme activity onto silicon microparticles was best achieved by using the undecylenic acid functionalization technique (route A), whereas, onto silica, non-significant differences in the CiP activity were found when using either route $A$ or B. In comparison to immobilization studies using HRP, relatively lower activity was observed for the immobilized HRP. Note that the size of CiP was slightly bigger than HRP (approx. 6.8 x $4.6 \mathrm{~nm}$ [79]); however, immobilized CiP exhibited 10-fold higher activity than the immobilized HRP. This could be due to the improper orientation of HRP inside the pores of the materials or a possible 'masking effect' due to the presence of a large amount of enzyme inside the pores, which, if it occurs may contribute towards the inaccessibility of the active site. Additionally, a mass transfer effect is possible which would inhibit transfer of the substrate and the product formed within the immobilized system [80]. Further studies are needed to fully understand the effect of immobilization on these and other enzymes.

\section{Conclusions}

This work shows the potential of biosilica extracted from a rarely studied plant material (Equisetum Myriochaetum), its conversion to silicon and possible applications of both biogenic materials as supports for enzyme immobilization. The \% yield of silica extracted from Equisetum myriochaetum was remarkably much higher (up to 3 times more) than other Equisetum ssp. (i.e. E. Arvense) previously studied. The isolated silica contained no heavy metals such as $\mathrm{Pb}$ and had purity higher than $95 \%$ where the remaining $\%$ was attributed to traces of other biominerals that can be present in these samples (i.e. $\mathrm{KCl}$ ). The surface area and pore size of the biogenic silica was $\sim 400 \mathrm{~m}^{2} \cdot \mathrm{g}^{-1}$ and $\sim 5 \mathrm{~nm}$, respectively, which made this material attractive for biotechnological applications. The extracted amorphous silica was readily reduced to crystalline silicon with surface area and pore 
size of the new material being $287 \mathrm{~m}^{2} \cdot \mathrm{g}^{-1}$ and $\sim 12 \mathrm{~nm}$, respectively. Enzyme immobilization assays showed that the presence of the aldehyde linker $(B)$ onto the silica surface enabled a significantly greater enzyme (in this case HRP) loading compared to the other routes tested. The loading and enzyme capacity of peroxidase from Coprinus cinereus was then compared with silicon showing the greatest enzyme activity for surfaces functionalised with carbodiimide (A), and a lower activity for silicon compared to silica was found for materials prepared using the glutaraldehyde immobilization technique (route B). In general, enzyme activity was found to be higher for $\mathrm{CiP}$ than for HRP for all biogenic materials. From the properties of the extracted materials obtained from Equisetum Myriochaetum and the immobilization results observed, these materials appear to be promising for industrial and biomedical applications.

Acknowledgement: This work has been financially supported by Institutional links CONACyT-British Council (\# 247886). We acknowledge the useful discussions and initiative taken by Dr. Julia Tagúeña Parga for developing this collaboration.

\section{References}

[1] Page CN. An interpretation of the morphology and evolution of the cone and shoot of Equisetum. Bot J Linn Soc 1972;65:359-397.

[2] Perry C, Fraser M. Silica deposition and ultrastructure in the cell wall of Equisetum arvense: the importance of cell wall structures and flow control in biosilicification? Philos Trans R Soc Lond B Biol Sci 1991;334:149-157.

[3] Grégoire C, Rémus-Borel W, Vivancos J, Labbé C, Belzile F, Bélanger RR. Discovery of a multigene family of aquaporin silicon transporters in the primitive plant Equisetum arvense. The Plant Journal 2012;72:320-330.

[4] Hodson M, White PJ, Mead A, Broadley M. Phylogenetic variation in the silicon composition of plants. Ann Bot 2005;96:1027-1046.

[5] Mann S, Perry CC, Williams RJ, Fyfe CA, Gobbi GC, Kennedy GJ. The characterisation of the nature of silica in biological systems. J Chem Soc 1983;4:168-170.

[6] Perry CC, Mann S, Williams R, Watt F, Grime G, Takacs J. A scanning proton microprobe study of macrohairs from the lemma of the grass Phalaris canariensis L. 1984;222:439-445.

[7] Cooke J, Leishman MR. Is plant ecology more siliceous than we realise? Trends Plant Sci 2011;16:61-68.

[8] Neethirajan S, Gordon R, Wang L. Potential of silica bodies (phytoliths) for nanotechnology. Trends Biotechnol 2009;27:461-467.

[9] Davis ME. Ordered porous materials for emerging applications. Nature 2002;417:813-821.

[10] Slowing II, Trewyn BG, Giri S, Lin V. Mesoporous silica nanoparticles for drug delivery and biosensing applications. Adv Funct Mater 2007;17:1225-1236.

[11] Perry CC. Silicification: the processes by which organisms capture and mineralize silica. Re. Mineral Geochem 2003;54:291-327

[12] Perry CC, Lu Y. Preparation of silicas from silicon complexes: role of cellulose in polymerisation and aggregation control. J Chem Soc Faraday Trans 1992;88:2915-2921. 
[13] Bauer P, Elbaum R, Weiss IM. Calcium and silicon mineralization in land plants: transport, structure and function. Plant Sci 2011;180:746-756.

[14] Cseke LJ, Kirakosyan A, Kaufman PB, Warber S, Duke JA, Brielmann HL. Natural products from plants. New York: CRC press, 2016.

[15] Currie HA, Perry CC. Silica in plants: biological, biochemical and chemical studies. Ann Bot 2007;100:1383-1389.

[16] Sola-Rabada A, Rinck J, Belton DJ, Powell AK, Perry CC. Isolation of a wide range of minerals from a thermally treated plant: Equisetum arvense, a Mare's tale. J Biol Inorg Chem 2016;21:1-12.

[17] Sapei L, Gierlinger N, Hartmann J, Nöske R, Strauch P, Paris O. Structural and analytical studies of silica accumulations in Equisetum hyemale. Anal Bioanal Chem 2007;389:1249-1257.

[18] Guillon J. Phylogeny of horsetails (Equisetum) based on the chloroplast rps4 gene and adjacent noncoding sequences. Syst Bot 2004;29:251-259.

[19] Glenday C. Guinness world records 2015. [New York]: Guinness World Records Limited, 2014. p 68-68.

[20] Andrade-Cetto A, Heinrich M. Mexican plants with hypoglycaemic effect used in the treatment of diabetes. J Ethnopharmacol 2005;99:325-348.

[21] Gutiérrez RF, Laguna GY, Walkowski A. Diuretic activity of Mexican equisetum. J Ethnopharmacol 1985;14:269-272.

[22] Téllez MGO, Rodríguez HB, Olivares GQ, Sortibrán ANC, Cetto AA, Rodríguez-Arnaiz R. A phytotherapeutic extract of Equisetum myriochaetum is not genotoxic either in the in vivo wing somatic test of Drosophila or in the in vitro human micronucleus test. J Ethnopharmacol 2007;111:182-189.

[23] Carlquist S, Schneider EL. Equisetum xylem: SEM studies and their implications. Am Fern J 2011;101:133-141. [24] Hauke RL. A Resume of the Taxonomic Reorganization of Equisetum, Subgenus Hippochaete, IV. Am Fern J 1962;:123130.

[25] Bolivar JM, Schelch S, Mayr T, Nidetzky B. Mesoporous silica materials labeled for optical oxygen sensing and their application to development of a silica-supported oxidoreductase biocatalyst. ACS Catal 2015;5:5984-5993.

[26] Hartmann M, Kostrov X. Immobilization of enzymes on porous silicas-benefits and challenges. Chem Soc Rev 2013;42:6277-6289.

[27] Sheldon RA, van Pelt S. Enzyme immobilisation in biocatalysis: why, what and how. Chem Soc Rev 2013;42:6223-6235. [28] Letant SE, Hart BR, Kane SR, Hadi MZ, Shields SJ, Reynolds JG. Enzyme immobilization on porous silicon surfaces. Adv Mater 2004;16:689-693.

[29] Chaudhari PS, Gokarna A, Kulkarni M, Karve M, Bhoraskar S. Porous silicon as an entrapping matrix for the immobilization of urease. Sensors Actuators B: Chem 2005;107:258-263. 
[30] Sahare P, Ayala M, Vazquez-Duhalt R, Agrawal V. Immobilization of peroxidase enzyme onto the porous silicon structure for enhancing its activity and stability. Nanoscale Res Lett 2014;9:1.

[31] Saleem M, Rafiq M, Seo SY, Lee KH. Acetylcholinesterase immobilization and characterization, and comparison of the activity of the porous silicon-immobilized enzyme with its free counterpart. Biosci Rep 2016;36:10.

[32] DeLouise LA, Miller BL. Enzyme immobilization in porous silicon: quantitative analysis of the kinetic parameters for glutathione-S-transferases. Anal Chem 2005;77:1950-1956.

[33] Velleman L, Shearer CJ, Ellis AV, Losic D, Voelcker NH, Shapter JG. Fabrication of self-supporting porous silicon membranes and tuning transport properties by surface functionalization. Nanoscale 2010;2:1756-1761.

[34] Peres HE, Galeazzo E, Dantas MO, Ramirez-Fernandez FJ. Porous silicon masking by silicon oxide and hydrogen ion implantation. Proceeding of the XVI International Conference on Microelectronics and Packaging, SBmicro 2001;:118-121. [35] Canham L. Porous Silicon Application Survey. In: Canham L, editor. Handbook of Porous Silicon. Switzerland: Springer, 2014. p 733-740.

[36] Park J, Gu L, Von Maltzahn G, Ruoslahti E, Bhatia SN, Sailor MJ. Biodegradable luminescent porous silicon nanoparticles for in vivo applications. Nat Mater 2009;8:331-336.

[37] Föll H, Christophersen M, Carstensen J, Hasse G. Formation and application of porous silicon. Mater Sci Eng R Rep 2002;39:93-141.

[38] Archer M, Christophersen M, Fauchet P. Electrical porous silicon chemical sensor for detection of organic solvents. Sensors Actuators B: Chem 2005;106:347-357.

[39] Baker C, Gole J. Interface modifications of porous silicon for chemical sensor applications. JSM Nanotechnol Nanomed 2014;2:1021.

[40] Liu R, Schmedake TA, Li YY, Sailor MJ, Fainman Y. Novel porous silicon vapor sensor based on polarization interferometry. Sensors Actuators B: Chem 2002;87:58-62.

[41] De Stefano L, Arcari P, Lamberti A, Sanges C, Rotiroti L, Rea I, Rendina I. DNA optical detection based on porous silicon technology: from biosensors to biochips. Sensors 2007;7:214-221.

[42] Pacholski C, Sartor M, Sailor MJ, Cunin F, Miskelly GM. Biosensing using porous silicon double-layer interferometers: reflective interferometric Fourier transform spectroscopy. J Am Chem Soc 2005;127:11636-11645.

[43] Dantas MO, Galeazzo E, Peres HE, Kopelvski MM, Ramirez-Fernandez FJ. Silicon Field-Emission Devices Fabricated Using the Hydrogen Implantation-Porous Silicon (HI-PS) Micromachining Technique. J Microelectromech Syst 2008;17:12631269.

[44] Canham L, Stewart M, Buriak J, Reeves C, Anderson M, Squire E, Allcock P, et al. Derivatized porous silicon mirrors: implantable optical components with slow resorbability. Phys. Status Solidi A 2000;182:521-525. 
[45] Boukherroub R, Petit A, Loupy A, Chazalviel J, Ozanam F. Microwave-assisted chemical functionalization of hydrogenterminated porous silicon surfaces. J Phys Chem B 2003;107:13459-13462.

[46] Rivolo P, Severino SM, Ricciardi S, Frascella F, Geobaldo F. Protein immobilization on nanoporous silicon functionalized by RF activated plasma polymerization of Acrylic Acid. J Colloid Interface Sci 2014;416:73-80.

[47] Zhao Y, Lawrie JL, Beavers KR, Laibinis PE, Weiss SM. Effect of DNA-induced corrosion on passivated porous silicon biosensors. ACS Appl Mater Interfaces 2014;6:13510-13519.

[48] Salonen J, Laitinen L, Kaukonen A, Tuura J, Björkqvist M, Heikkilä T, Vähä-Heikkilä K, et al. Mesoporous silicon microparticles for oral drug delivery: loading and release of five model drugs. J Controlled Release 2005;108:362-374.

[49] Sahare P, Ayala M, Vazquez-Duhalt R, Pal U, Loni A, Canham L, Osorio I, et al. Enhancement of Peroxidase Stability Against Oxidative Self-Inactivation by Co-immobilization with a Redox-Active Protein in Mesoporous Silicon and Silica Microparticles. Nanoscale Res Lett 2016;11:417.

[50] Brunauer S, Emmett PH, Teller E. Adsorption of gases in multimolecular layers. J Am Chem Soc 1938;60:309-319.

[51] Barrett EP, Joyner LG, Halenda PP. The determination of pore volume and area distributions in porous substances. I. Computations from nitrogen isotherms. J Am Chem Soc 1951;73:373-380.

[52] Cullen E, Rudall PJ. The remarkable stomata of horsetails (Equisetum): patterning, ultrastructure and development. Ann Bot 2016;118:207-218.

[53] Sven S. Sodium. In: Barker AV, Pilbeam DJ, editors. Handbook of plant nutrition. New York: CRC Press, 2015. p 697710.

[54] Park S, Baker JO, Himmel ME, Parilla PA, Johnson DK. Research cellulose crystallinity index: measurement techniques and their impact on interpreting cellulase performance. Biotechnol Biofuels 2010;3:1-10.

[55] Perez S, Mazeau K. Conformations, Structures, and Morphologies of Cellulose. In: Dumitriu S, editor. Polysaccharides : structural diversity and functional versatility. Second Edition ed. New York: Marcel Dekker, 1998. p 41-68.

[56] Tang S, Baker GA, Ravula S, Jones JE, Zhao H. PEG-functionalized ionic liquids for cellulose dissolution and saccharification. Green Chem 2012;14:2922-2932.

[57] Yang H, Yan R, Chen H, Lee DH, Zheng C. Characteristics of hemicellulose, cellulose and lignin pyrolysis. Fuel 2007;86:1781-1788.

[58] Lv D, Xu M, Liu X, Zhan Z, Li Z, Yao H. Effect of cellulose, lignin, alkali and alkaline earth metallic species on biomass pyrolysis and gasification. Fuel Process Technol 2010;91:903-909.

[59] Wiedemann $\mathrm{H}$. Thermal analysis of the wood components in relation to the growth period of a tree. Thermochim Acta 1993;229:215-228.

[60] Beall F. Differential calometric analysis of wood and wood components. Wood Sci Technol 1971;5:159-175. 
[61] Zhuravlev L. The surface chemistry of amorphous silica. Zhuravlev model. Colloid Surf A-Physicochem Eng Asp $2000 ; 173: 1-38$

[62] Smith AL. Infrared spectra-structure correlations for organosilicon compounds. Spectrochimica Acta 1960;16:87-105.

[63] Aines RD, Rossman GR. Water in minerals? A peak in the infrared. J Geophys Res Solid Earth 1984;89:4059-4071.

[64] Smith BC. Infrared spectral interpretation: a systematic approach. London: CRC press, 1998.

[65] Perry CC, Li X. Structural studies of gel phases. Part 1._-Infrared spectroscopic study of silica monoliths; the effect of thermal history on structure. J Chem Soc Faraday Trans 1991;87:761-766.

[66] lacona F, Bongiorno C, Spinella C, Boninelli S, Priolo F. Formation and evolution of luminescent Si nanoclusters produced by thermal annealing of SiO x films. J Appl Phys 2004;95:3723-3732.

[67] Ogata YH. Characterization of porous silicon by infrared spectroscopy. In: Canham L, editor. Handbook of Porous Silicon. Switzerland: Springer, 2014. p 473-480.

[68] Mello MR, Phanon D, Silveira GQ, Llewellyn PL, Ronconi CM. Amine-modified MCM-41 mesoporous silica for carbon dioxide capture. Microporous Mesoporous Mater 2011;143:174-179.

[69] Almeida PV, Shahbazi M, Mäkilä E, Kaasalainen M, Salonen J, Hirvonen J, Santos HA. Amine-modified hyaluronic acidfunctionalized porous silicon nanoparticles for targeting breast cancer tumors. Nanoscale 2014;6:10377-10387.

[70] Margel S, Rembaum A. Synthesis and characterization of poly (glutaraldehyde). A potential reagent for protein immobilization and cell separation. Macromolecules 1980;13:19-24.

[71] Barth A. Infrared spectroscopy of proteins. Biochimica et Biophysica Acta (BBA)-Bioenergetics 2007;1767:1073-1101.

[72] Zdarta J, Jesionowski T. Amano Lipase A grafting onto a silica surface. BioTechnologia Journal of Biotechnology Computational Biology and Bionanotechnology 2013;94.

[73] Figueiredo M, Gamelas J, Martins A. Characterization of bone and bone-based graft materials using FTIR spectroscopy. In: Theophile T, editor. Infrared Spectroscopy-Life and Biomedical Sciences. Croatia: InTech, 2012. p 315-338.

[74] Zhang D, Hegab HE, Lvov Y, Snow LD, Palmer J. Immobilization of cellulase on a silica gel substrate modified using a 3APTES self-assembled monolayer. SpringerPlus 2016;5:48.

[75] Majoul N, Aouida S, Bessaïs B. Progress of porous silicon APTES-functionalization by FTIR investigations. Appl Surf Sci 2015;331:388-391.

[76] Li SY, Ma W, Zhou Y, Chen X, Ma M, Xu Y, Ding Z, et al. 3-aminopropyltriethoxysilanes modified porous silicon as a voltammetric sensor for determination of Silver ion. Int J Electrochem Sci 2013;8:1802-1812.

[77] Takahashi H, Li B, Sasaki T, Miyazaki C, Kajino T, Inagaki S. Catalytic activity in organic solvents and stability of immobilized enzymes depend on the pore size and surface characteristics of mesoporous silica. Chem Mater 2000;12:3301 3305. 
[78] Patwardhan SV, Emami FS, Berry RJ, Jones SE, Naik RR, Deschaume O, Heinz H, et al. Chemistry of aqueous silica nanoparticle surfaces and the mechanism of selective peptide adsorption. J Am Chem Soc 2012;134:6244-6256.

[79] Houborg K, Harris P, Petersen J, Rowland P, Poulsen J, Schneider P, Vind J, Larsen S. Impact of the physical and chemical environment on the molecular structure of Coprinus cinereus peroxidase. Acta Crystallogr D Biol Crystallogr 2003;59:989-996.

[80] Halim SFA, Kamaruddin AH, Fernando W. Continuous biosynthesis of biodiesel from waste cooking palm oil in a packed bed reactor: optimization using response surface methodology (RSM) and mass transfer studies. Bioresour Technol 2009;100:710-716. 